ON human endothelial cells from umbilical cord (HUVEC) are present, in addition to E-and P-selectins, their cognate ligands. Differently from selectins, the ligand expression is constitutive and not modulated by interleukin-1 $\beta$. Such ligands appear to be different from the ones present in promyelocytic cells in order to promote cell adhesion to immobilized selectins. The expression of selectin-ligands on HUVEC cells suggest that selectins can participate in endothelial signalling besides their role as adhesion molecules for circulating blood cells. How ever, despite their role in chemotaxis, selectins do not contribute to HUVEC tube formation in Matrigel.

Key words: adhesion molecules, selectin ligand, tube formation, endothelial adhesion, HUVEC

\section{Constitutive expression of E-and P-selectin cognate ligands in human endothelial cells}

\author{
C. Palma, ${ }^{1, C A}$ D. Bellarosa, ${ }^{1}$ F. Nardelli, ${ }^{1}$ G. Mannori ${ }^{2}$ \\ and S. Manzini ${ }^{1}$
}

\author{
${ }^{1}$ Menarini Ricerche S.p.A. Department of \\ Pharmacology, Via Tito Speri 10, 00040 Pomezia, \\ Rome, Italy; ${ }^{2}$ Istituto Patologia Generale, Università \\ degli Studi di Firenze, Viale Morgagni 50,50134 \\ Firenze, Italy
}
${ }^{\mathrm{CA}}$ Corresponding Author
Tel: $(+39) 691184463$
Fax: $(+39) 69100220$

\section{Introduction}

The selectins initiate many critical interactions among blood cells and the vascular system. The recognition between E- and P-selectins expressed on activated endothelium and cognate ligands expressed on myeloid and lymphoid cells mediates the initial attachment of leukocytes to venular endothelial cells before their firm adhesion and diapedesis at sites of tissue injury and inflammation. ${ }^{1}$ Besides their main role as adhesion molecules, selectins have been reported to participate in angiogenesis responses. ${ }^{2}$ Soluble E-selectin has been demonstrated to promote human endothelial cell migration and to stimulate angiogenesis in the rat cornea. ${ }^{3}$ In an in vitro model of angiogenesis, the formation of tube-like structures by bovine capillary endothelial cells was inhibited by the addition of an anti-E selectin antibody. ${ }^{4}$ P-selectin, as well as E-selectin, recognizes sialylated glycans such as sialyl-Lew is $\mathrm{X}$ and sialyl-Lew is A containing molecules. ${ }^{5}$ These molecules have also been implicated in capillary tube formation. ${ }^{4}$ Consistently, we recently reported that soluble P-selectin can also promote human and bovine endothelial cell migration. ${ }^{6}$ The expression of cognate ligands on endothelial cells is mandatory to support a role for selectins as molecules involved also in endothelial signalling and cross-talks. In this study we have assessed whe ther quiescent or interleukin-1 $\beta$ (IL-1 $\beta$ ) primed cultured human endothelial cells possess molecules able to recognize E- and P-selectins and their effect in mediating endothelial functions such as adhesion and morphogenesis of capillary-like structures.

\section{Materials and Methods}

\section{Cell lines and culture conditions}

Human umbilical cord vein endothelial cells (HUVEC) were isolated with collagenase perfusion of term umbilical cords as previously described ${ }^{7}$ and primary cultures were used in the experiments. HUVEC were grown in Medium 199 supplemented with $10 \%$ heat-inactivated fetal calf serum $\left(65^{\circ} \mathrm{C}\right.$, $30 \mathrm{~min})$. Undifferentiated human promyelocytic cell lines HL-60 and U937, obtained from the American Type Culture Collection (Rockville, MD), were mantained in RPMI 1640 containing 10\% heat-inactivated fetal bovine serum.

\section{Reagents}

Human recombinant basic fibroblast growth factor (bFGF) was purchased from Boehringer Mannheim (Germany). Human soluble E- and P-selectins were purchased from R\&D System Europe Ltd, Abingdon, UK. The E-selectin-immunoglobulin fusion protein was kindly provided by Dr M. Bevilacqua. The following murine monoclonal antibodies (MoAb) were used: anti-human E-selectin, BBA 2 (R\&D System Europe Ltd); anti-human P-selectin, AC1.2 and BMS126 (Becton Dickinson, San Jose, CA and Bender Med-System, Vienna, Austria, respectively); anti-SialylLew is X, CSLEX1 (Becton Dickinson). The second step antibody conjugates were: alkaline phosphatase goat anti-mouse total immunoglobulin (Ig) (Oncogene 
Research Products, Cambridge, MA); alkaline-phosphatase conjugated goat anti-human IgG (Fc specific) (SIGMA Chemical Co., St Louis, MO).

\section{Cell-ELISA assays}

Confluent HUVEC $\left(5 \times 10^{4}\right.$ cells/well $)$ stimulated or not with $100 \mathrm{U} / \mathrm{ml}$ of recombinant human IL-1 $\beta$ (specific activity $1.3 \times 10^{7} \mathrm{U} / \mathrm{mg}$; Janssen Biochimica, Beerse, Belgium) for $4 \mathrm{~h}$ at $37^{\circ} \mathrm{C}$ or HL-60 cells $\left(3 \times 10^{5}\right.$ cells/well; immobilized on 96-well plates coated with $0.1 \mathrm{mg} / \mathrm{ml}$ of poly-D-lysine, $\mathrm{MW}>$ 300000 ; Sigma) were used in cell-ELISA experiments. Briefly, cells were washed in PBS and incubated for $1 \mathrm{~h}$ at $4^{\circ} \mathrm{C}$ in PBS containing $1 \%$ bovine serum albumin with primary MoAbs, the EselectinIg fusion protein or the complex formed by soluble P-selectin and the corresponding non-neutralizing $\mathrm{MoAb} A C 1.2$. After washings, the appropriate alkaline-phosphatase conjugated goat anti-mouse total Ig or anti-human $\operatorname{IgG}$ were added to the wells for $45 \mathrm{~min}$. Specific binding was calculated by subtracting the signal generated (conversion of phosphatase substrate) in the wells containing cells treated only with the appropriate alkaline-phosphatase conjugated goat anti-Ig. All samples were assayed in triplicate.

\section{Cell adhesion assay}

Cell adhesion assays were based on the procedure of Martens et al., ${ }^{8}$ with some modifications. Briefly, soluble $\mathrm{E}-$ and P-selectins were immobilized on 96-well plates in carbonate buffer $\mathrm{NaHCO}_{3} \mathrm{Na}_{2} \mathrm{CO}_{3}$ $0.05 \mathrm{M} \mathrm{pH} 9.6 \quad\left(5 \mu \mathrm{g} / \mathrm{ml}\right.$ overnight at $4^{\circ} \mathrm{C}$ and $10 \mu \mathrm{g} / \mathrm{ml} 1 \mathrm{~h}$ at room temperature for $\mathrm{E}-$ and P-selectins, respectively). The plates were then saturated with PBS containing $1 \%$ bovine serum albumin. HL-60, U937 and HUVEC cells (stimulated or not with $100 \mathrm{U} / \mathrm{ml}$ of recombinant human IL-1 $\beta$ for $4 \mathrm{~h}$ at $37^{\circ} \mathrm{C}$ and then detached from culture plates by trypsinization) were added at $2 \times 10^{5}$ cells $/$ well to the selectin-coated wells and incubated at room temperature for $45 \mathrm{~min}$. Non-specific binding was determined in wells treated only with carbonate buffer. Wells were washed gently twice with PBS and the adherent cells were labelled with $0.5 \mathrm{mg} / \mathrm{ml}$ 3-(4,5-dimethylthiazol-2-yl)-2,5-diphenyltetrazolium bromide (MTT). The absorbance was read in a photometer Microplate 3550 at two wavelengths (690 $\mathrm{nm}$ and $570 \mathrm{~nm}$ as reference). In some experiments, HL-60 and U937 cells labelled with $2 \mu \mathrm{Ci} / \mathrm{ml}$ $\left[{ }^{3} \mathrm{H}\right]$-methyl-thymidine (NEN-Du Pont DeNemours Italiana, Cologno Monzese (MI), Italy, $82.5 \mathrm{Ci} / \mathrm{mmol}$ ) for $18 \mathrm{~h}$, were used for the cell adhesion assays. ${ }^{3} \mathrm{H}$ radioactivity was determined by counting in a Wallac Betaplate $^{\mathrm{TM}}$ liquid scintillation counter.

\section{In vitro angiogenesis model}

Morphogenetic experiments were performed according to the procedures of Wiedermann et al. ${ }^{9}$ Briefly, a comple te differentiation of HUVEC into capillary-like structures, was achieved by coating 24-well plates with $300 \mu \mathrm{l}$ of Matrigel (Becton Dickinson, Bedford, MA, USA) per well, which was allowed to polymerize at $37^{\circ} \mathrm{C}$ for $30 \mathrm{~min}$. For suboptimal stimulation of HUVEC differentiation, $300 \mu \mathrm{l}$ per well of diluted Matrigel (1:2 with Medium 199) was kept at $4^{\circ} \mathrm{C}$ overnight for slow polymerization, followed by $37^{\circ} \mathrm{C}$ for $30 \mathrm{~min}$ before use. These suboptimal conditions were selected in order to better detect factors that promote tube-formation. HUVEC were suspended in Medium $199+10 \%$ FCS $\left(10^{5}\right.$ cells per well $)$, incubated for $30-40 \mathrm{~min}$ at $37^{\circ} \mathrm{C}$ with different concentrations of test substances and then plated on diluted Matrigel. Each condition was tested in triplicate wells. After $12-18 \mathrm{~h}$ of incubation at $37^{\circ} \mathrm{C}$ in $5 \%$ $\mathrm{CO}_{2}$, the capillary-like structures were observed by inverted microscopy and quantitatively evaluated counting tubular formations $\geq 300 \mu \mathrm{m}$ at $30 \times$ magnification and using an ocular grid.

\section{Results}

\section{Cognate ligands for E- or P-selectins in HUVEC cells}

To determine whether HUVECcells ex press ligands for selectins, cell ELSA experiments were performed using the E-selectin-immunoglobulin fusion protein to recognize structures that bind Eselectin and a complex of soluble P-selectin with a corresponding nonneutralizing $\mathrm{MoAb}(\mathrm{ACl} .2)$ to recognize ligands for $\mathrm{P}$ selectin. Moreover, MoAbs against sialyl-Lew is X, E-selectin and P-selectin were applied. The human promyelocitic cell line HL-60 immobilized on plate surface coated with poly-D-lysine, endowed with P- and E-selectin ligands, ${ }^{10,11}$ was used as a positive control. As shown in Table 1, molecular structures able to bind both E-and P-selectin were found on cultured HUVEC cells. The MoAb CSLEX1 that recognizes sialyl-Lewis $\mathrm{X}^{12}$ a carbohydrate mojety bearing on ligands for selectins, ${ }^{5}$ did not react above the background levels on HUVEC cells while was strongly recognized on HL60. As expected, the reactivity of $\mathrm{MoAb}$ against Eselectin was detected only on HUVEC stimulated with IL-1 $\beta$ while no reactivity for P-selectin was found. On the other hand, IL-1 $\beta$ exposure did not affect the expression of E-or P-selectin cognate ligands.

\section{Role of E- and P-selectin cognate ligands on cell adhesion mediated by immobilized selectins}

The function of ligands for E- and P-selectins expressed on HUVEC was checked on adhesion assays to immobilized selectins in static conditions. As 
Table 1. Detection of selectins and their cognate ligands on HUVEC and HL-60 cells through cell-ELISA assays

\begin{tabular}{|c|c|c|c|}
\hline & \multicolumn{2}{|c|}{ HUVEC } & \multirow[t]{2}{*}{$\mathrm{HL}-60$} \\
\hline & Unstimulated & IL-1 $\beta$-stimulated & \\
\hline $\begin{array}{l}\text { MoAb anti-sialyl-Lewis X } \\
\text { (CSLEX } 5 \mu \mathrm{g} / \mathrm{ml} \text { ) }\end{array}$ & $0 \pm 0^{\mathrm{a}}$ & $0 \pm 0$ & $0.673 \pm 0.01$ \\
\hline $\begin{array}{l}\text { MoAb anti E-selectin } \\
\text { (BBA2 } 10 \mu \mathrm{g} / \mathrm{ml} \text { ) }\end{array}$ & $0 \pm 0$ & $0.746 \pm 0.04$ & $0 \pm 0$ \\
\hline $\begin{array}{l}\text { MoAb anti P-selectin } \\
\text { (AC1.2 } 10 \mu \mathrm{g} / \mathrm{ml})\end{array}$ & $0 \pm 0$ & $0 \pm 0$ & $0 \pm 0$ \\
\hline $\begin{array}{l}\text { P-selectin binding } \\
\text { (sP-selectin } 10 \mu \mathrm{g} / \mathrm{ml}+\text { MoAb AC1.2 } 10 \mu \mathrm{g} / \mathrm{ml})\end{array}$ & $0.533 \pm 0.1$ & $0.477 \pm 0.1$ & $0.445 \pm 0.1$ \\
\hline $\begin{array}{l}\text { E-selectin binding } \\
\text { (E-selectin-lg fusion protein } 50 \mu \mathrm{g} / \mathrm{ml} \text { ) }\end{array}$ & $0.113 \pm 0.03$ & $0.110 \pm 0.02$ & $0.126 \pm 0.01$ \\
\hline
\end{tabular}

a Mean of absorbance (obtained subtracting the signal generated in the wells containing cells treated only with the appropriate alkalinephosphatase conjugated goat anti-lg) \pm SD of three independent experiments.

shown in Table 2, HUVEC did not adhere to immobilized E- or P-selectin within 45 min of exposure time. Consistent with the lack of effect of IL-1 $\beta$ on selectinligand expression, the cytokine treatment did not improve HUVEC adhesion. The human cell line HL-60 and U937 which express ligands for selectins adhered strongly to immobilized E- or P-selectins. This adhesion was selective and specific since it was blocked by the respective neutralizing MoAbs against $\mathrm{E}-$ (BBA2) or P-selectins (BMS 126). In fact, MoAb BBA2 $(5 \mu \mathrm{g} / \mathrm{ml})$ inhibited HL-60 or U937 adhesion to immobilized E-selectin of $62 \pm 3.6 \%$ and $67 \pm 8 \%$ respectively $(n=3)$, while left inalterated the cell adhesion to Pselectin. Conversely, MoAb BMS126 $(10 \mu \mathrm{g} / \mathrm{ml})$ did not influence static adhesion to Eselectin but strongly blocked the HL-60 or U937 adhesion to P-selectin with inhibition of $92 \pm 1 \%$ or 87 $\pm 4 \%$ respectively $(n=3)$.

\section{Role of E- and P-selectins in in vitro assay for vascular morphogenesis}

We then assessed whether the presence of E- and P-selectin ligands on HUVEC cells could be instru- mental to morphogenetic processes required in angiogenesis. The addition to Matrigel diluted 1:2 of increasing concentrations of the angiogenic factor bFGF, dose-dependently stimulated HUVEC to progress from small fragments of unconnected tubes or cell aggregates into capillary-like structures within $18 \mathrm{~h}$ (Figs 1 and 2). However, soluble E-or P-selectins $(20-2000 \mathrm{ng} / \mathrm{ml})$ did not elicit HUVEC differentiation in Matrigel diluted 1:2 (Fig. 2) although the same concentrations were efficient in promoting HUVEC chemotaxis. ${ }^{3,6}$ In addition, soluble selectins or neutralizing MoAbs anti-E- or anti-P-selectin (BBA2 and BMS126 up to $20 \mu \mathrm{g} / \mathrm{ml}$ ) did not modulate bFGFinduced tube-formation (data not shown).

\section{Discussion}

The role of selectins in angiogenesis ${ }^{2}$ and in particular the effects of soluble E- and P-selectins on HUVEC migration reported by Koch and us, ${ }^{3,6}$ suggested the presence of receptive molecules for selectins on endothelial cells themselves. A cell-ELISA assay based on direct binding of E- and P-selectins was used to answer this question and also to overcome the aspect

Table 2. HL-60, U937 and HUVEC cells adhesion on immobilized E- and P-selectins in static assays

\begin{tabular}{|c|c|c|c|c|c|}
\hline \multirow[t]{2}{*}{ Cells ${ }^{a}$} & \multirow[t]{2}{*}{ Assays $^{b}$} & \multicolumn{4}{|c|}{ Adhesion } \\
\hline & & E-selectin & $\begin{array}{l}\text { Without } \\
\text { E-selectin }\end{array}$ & P-selectin & $\begin{array}{l}\text { Without } \\
\text { P-selectin }\end{array}$ \\
\hline HL-60 & $\begin{array}{l}\text { c.p.m. } \\
\text { o.d. }\end{array}$ & $\begin{array}{c}39639 \pm 6176^{c} \\
0.683 \pm 0.01\end{array}$ & $\begin{aligned} 387 & \pm 63 \\
0 & \pm 0\end{aligned}$ & $\begin{array}{c}18887 \pm 6176 \\
0.330 \pm 0.03\end{array}$ & $\begin{aligned} 148 & \pm 42 \\
0 & \pm 0\end{aligned}$ \\
\hline U937 & $\begin{array}{l}\text { c.p.m. } \\
\text { o.d. }\end{array}$ & $\begin{array}{c}19124 \pm 3907 \\
0.937 \pm 0.1\end{array}$ & $\begin{aligned} 357 & \pm 44 \\
0 & \pm 0\end{aligned}$ & $\begin{array}{c}17078 \pm 3870 \\
0.700 \pm 0.08\end{array}$ & $\begin{array}{c}436 \pm 124 \\
0 \pm 0\end{array}$ \\
\hline HUVEC & o.d. & $0 \pm 0$ & $0 \pm 0$ & $0 \pm 0$ & $0 \pm 0$ \\
\hline IL-1 $\beta$ stimulated HUVEC & o.d. & $0 \pm 0$ & $0 \pm 0$ & $0 \pm 0$ & $0 \pm 0$ \\
\hline
\end{tabular}

${ }^{a} \mathrm{HL}-60$, U937, HUVEC and IL-1 $\beta$-stimulated HUVEC cells $\left(2 \times 10^{5}\right.$ cells/well) were incubated for $1 \mathrm{~h}$ at R.T. in wells coated with immobilized E- and P-selectins or in wells treated only with carbonate buffer.

${ }^{b}$ The bound cells were expressed in c.p.m. in assays with radiolabelled cells or in o.d. in colorimetric assays.

'The results are reported as mean \pm SEM of three independent experiments. 

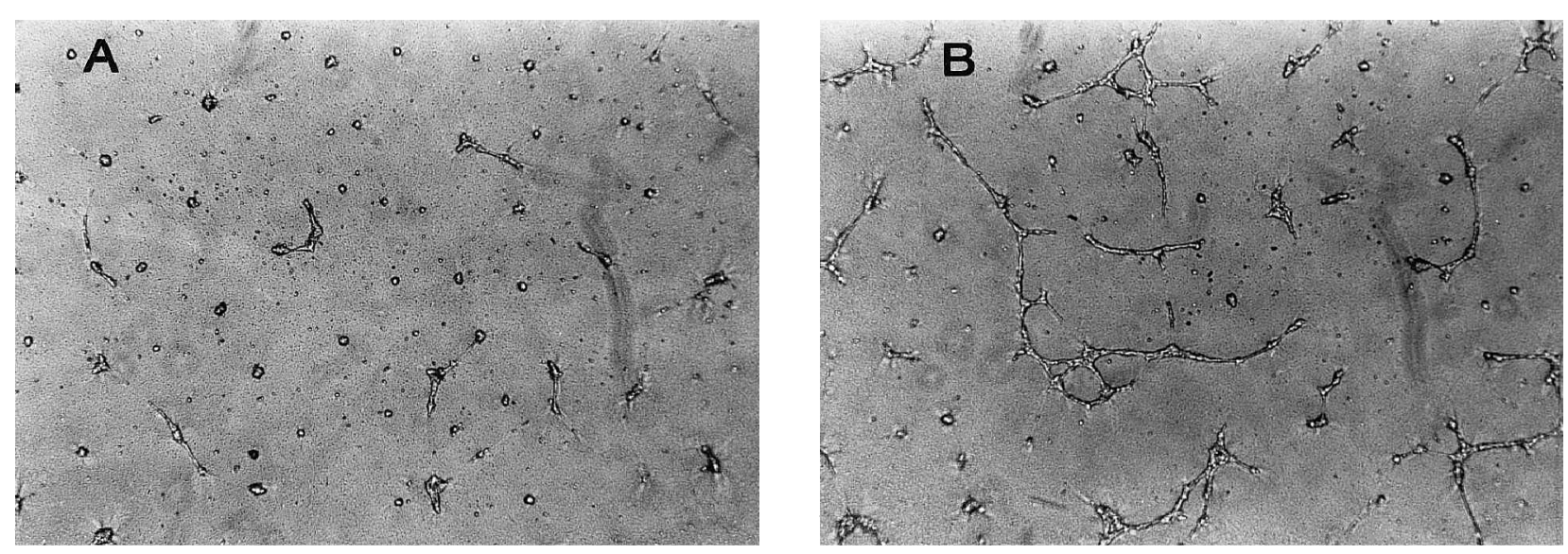

FIG. 1. Tube formation in Matrigel by HUVEC cells in the absence (A) or in the presence (B) of bFGF (20 ng/ml).

relative to the multiplicity of selectin ligands isolated until now in myeloid or cancer cells. ${ }^{5,13-15}$ In this experimental condition we identified a constitutive presence of cognate ligands for E-and P-selectins on HUVEC cells. These structures could be responsible for transducing signalling inside the cells, since the endothelial responses to soluble form of selectins. ${ }^{3,6}$ In addition, this ability was already proved for some E-selectin ligands, such as ESL-1, a variant of FGF receptor. ${ }^{16}$ The presence of such signalling-receptor on HUVEC cells may suggest that they can be activated not only by soluble selectins, present in blood circulation following shedding of membrane bound selectins, ${ }^{17}$ but also by the transmembrane selectins expressed in neighbouring activated endothelial cells or by the P-selectin present in platelets. Moreover they could be involved in activation of other endothelial functions during inflammatory process, besides their role in chemotaxis. In addition, the appearance of cellular function in response to such interactions is regulated by the presence of transmembrane or soluble selectins since expression of selectins arise following activation while selectin ligands are constitutively present on plasma mem-

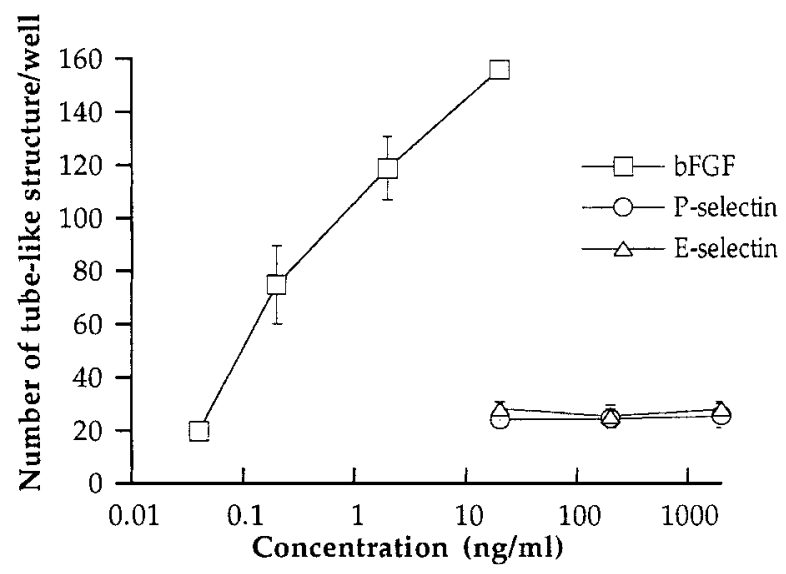

FIG. 2. Effect of bFGF and soluble E- and P-selectins on tube formation in Matrigel by HUVEC cells. The number of tubelike structures in unstimulated cells was $19 \pm 2$. brane and are not modulated by IL-1 $\beta$ stimulation. At present, we cannot exclude that the structure binding E-or P-selectins highlighted on endothelial cells in our experiments are the well-known L-selectin ligands. In fact it has been reported that an E-selectin-Ig chimera specifically stained HEV in mouse lymph nodes, as did an L-selectin-Ig chimera and precipitated GlyCAM-1 and $\mathrm{CD} 34 / \operatorname{Sgp} 90$ although with less efficiency than L-selectin. ${ }^{18}$ In any case, the finding of expression of cognate ligands for P-selectins is a novelty.

Since ligands for E- and P-selectins acts mainly as counter-receptor for adhesion molecules and mediate rolling and adhesion of inflammatory or cancer cells on endothelium we checked if the one expressed on HUVEC cells are able to mediate adherence to immobilized selectins through static adhesion assays. Unex pectedly, trypsinizated HUVEC cells were unable to adhere to E- or P-selectins even when stimulated with IL-1 $\beta$ according to the no increased expression of the selectin ligands after cytokine treatment. Trypsinization was not a limiting step in adhesion since it did not alter the expression of selectin ligands. In fact, HUVEC cells exposed to trypsinization showed an immunoreactivity for the complex able to bind cognate ligands for P-selectins similar to the one observed in HL-60 in FACS analysis, although this methodology was less sensitive than cell-ELISA (our unpublished observation). There was a pharmacological and functional difference in mediating adhesion response between selectin cognate ligands expressed on HUVEC and myeloid or cancer cells. The absence of HUVEC adhesion to selectins could be linked to the dissimilarity in their molecular structures but also to the unfavourable setting for endothelial cells or to a low or inappropriate density of selectin ligands expression. However, the structural differences between cognate ligands for selectins on HUVEC and HL-60 cells were pointed out by the immunoreactivity for the MoAb anti-sialyl-Lew is $\mathrm{X}$ (CSLEX1). Specific carbohydrate structures can function as ligands for selectins, interacting, at least in part, with their lectin domains. ${ }^{19-21}$ In general, 
ligands for E- and P-selectins bear moieties of sialylLew is $\mathrm{X}^{5}$ The antibody CSLEX1, which is able to inhibit the E-or P-selectin-mediated adhesion for nonlymphoid leukocytes and tumour cells of diverse origin ${ }^{11,15}$ was strongly recognized on HL-60 cells but not on HUVEC cells. However, we cannot rule out that sialyl-Lewis $\mathrm{X}$ moieties are present on cognate ligands for selectins expressed on HUVEC cells since monoclonal antibodies anti-sialyl-Lew is X (FH-6 and KM-93) other than CSLEX1 were strongly recognized by HUVEC cells. ${ }^{22}$

It has been reported that selectins contribute to angiogenesis but their relevance in neovascular development has been debated. Besides the effect of E-and P-selectin in HUVEC chemotaxis, ${ }^{3,6}$ we gathered evidence that they were not effective in switching on/ off the programme of formation of capillary-like structures on Matrigel. This event is a defined process that does not require extensive proliferation and where only some aspects of endothelial cell differentiation are involved. ${ }^{23}$ Therefore, we cannot exclude that in different experimental conditions (other extracellular matrix proteins or endothelial cells with different origins) selectins and their ligands could participate in the endothelial morphogenetic process. In addition, membrane selectins are not important in HUVEC capillary organization on Matrigel since neutralizing monoclonal antibodies directed against cell-surface E- or P-selectins did not inhibit basal or bFGF-induced tube-formation. This is in agreement with a recent paper describing that endothelial cells from Eselectin deficient mice form, without alteration, capillary-like structures on fibronectin, Matrigel and collagen gels in vitro. ${ }^{24}$

In conclusion, we have demonstrated the constitutive presence of E-and P-selectin cognate ligands on HUVEC cells that points out a new role(s) for this class of adhesion molecules as signalling factors for endothelial cells themselves.

\section{References}

1. Tedder TF, Steeber DA, Chen A, Engel P. The selectins: vascular adhesion molecules. FASEB J 1995; 9: 866-873.

2. Strömblad S, Cheresh, DA. Cell adhesion and angiogenesis. Trends Cell Biol 1996; 6: 462-468.
3. Koch AE, Halloran MM, Haskell CJ, Shah MR, Polverini PJ. Angiogenesis mediated by soluble forms of Eselectin and vascular cell adhesion molecule-1. Nature 1995; 376: 517-519.

4. Nguyen M, Strubel NA, Bischoff J. A role for sialyl Lewis-X/A glycoconjugates in capillary morphogenesis. Nature 1993; 365: 267-269.

5. Rosen SD, Bertozzi CR. The selectins and their ligands. Curr Opin Cell Biol 1994; 6: 663-673.

6. Brogelli L, Morbidelli L, Giani S, Palma C, Ziche M. Role of matrix component in the endothelial cell migration by soluble E and P selectin. XXVIII National Congress of the Italian Pharmacological Society, Bari, Italy 1997; 15

7. Jaffe EA, Nachman RL, Becker CG, Minick CR. Culture of human endothelial cells derived from umbilical veins. J Clin Invest 1973; 52: 2745-2756.

8. Martens CL, Cwirla SE, Lee RYW, et al. Peptides which bind to Eselectin and block neutrophil adhesion. J Biol Chem 1995; 270: 21129-21136.

9. Wiedermann CJ, Auer B, Sitte B, Reinisch N, Schratzberger P, Kähler CM Induction of endothelial cell differentiation into capillary-like structures by substance P. Eur J Pharmacol 1996; 298: 335-338.

10. Aruffo A, Kolanus W, Walz G, Fredman P, Seed B. CD62/P-selectin recognition on myeloid and tumor cell sulfatides. Cell 1991; 67: 35-44.

11. Walz G, Aruffo A, Kolanus W, Bevilacqua M, Seed B. Recognition by Elam1 of the sialyl-Le ${ }^{\mathrm{x}}$ determinant on myeloid and tumor cells. Science 1990; 250: $1132-1135$.

12. Fukushima K, Hirota M, Te rasaki PI, et al. Characterization of sialosylated Lew is $\mathrm{x}$ as a new tumor-associated antigen. Cancer Res 1984; 44: 5279-5285.

13. Varki A. Selectin ligands. Proc Natl Acad Sci 1994; 91: 7390-7397.

14. Mannori G, Crottet P, Cecconi O, et al. Differential colon cancer cell adhesion to E-, P- and Lselectin: role of mucin-type glycoproteins. Cancer Res 1995; 55: 4425-4431.

15. Phillips ML, Nudleman E, Gaeta FC, et al. ELAM-1 mediates cell adhesion by recognition of a carbohydrate ligand, sialyl-Le ${ }^{\mathrm{x}}$. Science 1990; 250: $1130-1132$.

16. Steegmaier M, Levinovitz A, Isenmann S, et al. The E-selectin-ligand ESL-1 is a variant of a receptor for fibroblast grow th factor. Nature 1995; 373: 615-620.

17. Newman W, Beall LD, Carson CW, et al. Soluble Eselectin is found in supernatants of activated endothelial cells and is elevated in the serum of patients with septic shock. J Im munol 1993; 150: 644-654.

18. Mebius RE, Watson SR. L- and Eselectin can recognize the same naturally occurring ligands on high endothelial venules. I Immunol 1993; 151: 3252-3260.

19. Lasky LA. Selectin-carbohydrate interactions and the initiation of the inflammatory response. Annu Rev Biochem 1995; 64: 113-139.

20. Bevilacqua MP, Nelson RM Selectins. J Clin Invest 1993; 91: 379-387.

21. Kansas GS. Selectins and their ligands: current concepts and controversies. Blood 1996; 88: 3259-3287.

22. Majuri M-L, Pinola M, Niemela R, et al. $\alpha 2.3$-Sialyl and $\alpha 1.3$ fucosyltransferase-dependent synthesis of sialyl-Le ${ }^{\mathrm{x}}$, an essential oligosaccharide present on L-selectin countereceptors, in cultured endothelial cells. Eur I Imm unol 1994; 24: 3205-3210.

23. Kubota Y, Kleinman HK, Martin GR, Lawley TJ. Role of laminin and basement membrane in the morphological differentiation of human endothelial cells into capillary-like structures. J Cell Biol 1988; 107: 1589-1598.

24. Gerristen ME, Shen CP, Atkinson WJ, Padgett RC, Gimbrone MA Jr, Milstone DS. Microvascular endothelial cells from Eselectin-deficient mice form tubes in vitro. Lab Invest 1996; 75: 175-184.

ACKNOWLEDGEMENTS. We are grateful to Drs M. Ziche, L Morbidelli and L. Brogelli (Università di Firenze, Firenze, Italy) for their helpful discussion.

\section{Received 27 January 1998; accepted 9 March 1998}




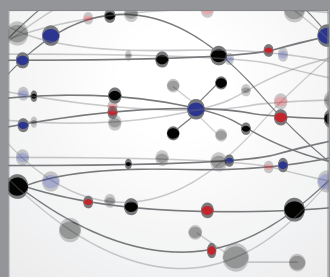

The Scientific World Journal
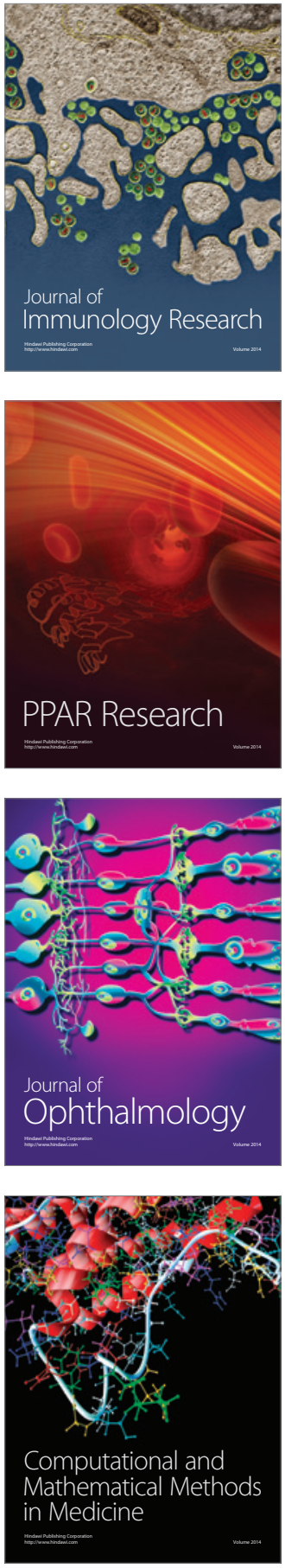

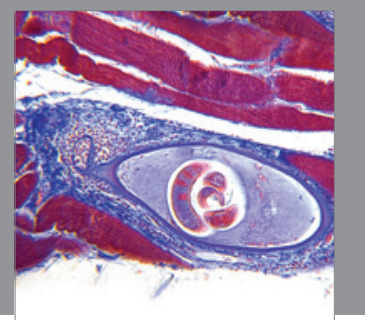

Gastroenterology

Research and Practice
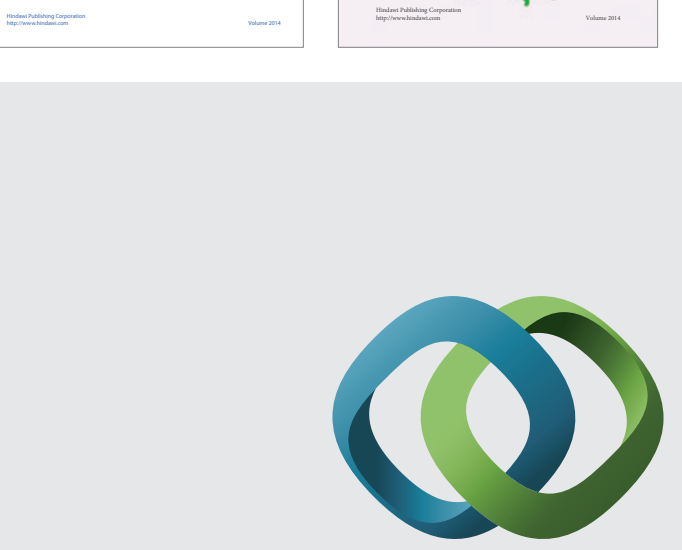

\section{Hindawi}

Submit your manuscripts at

http://www.hindawi.com
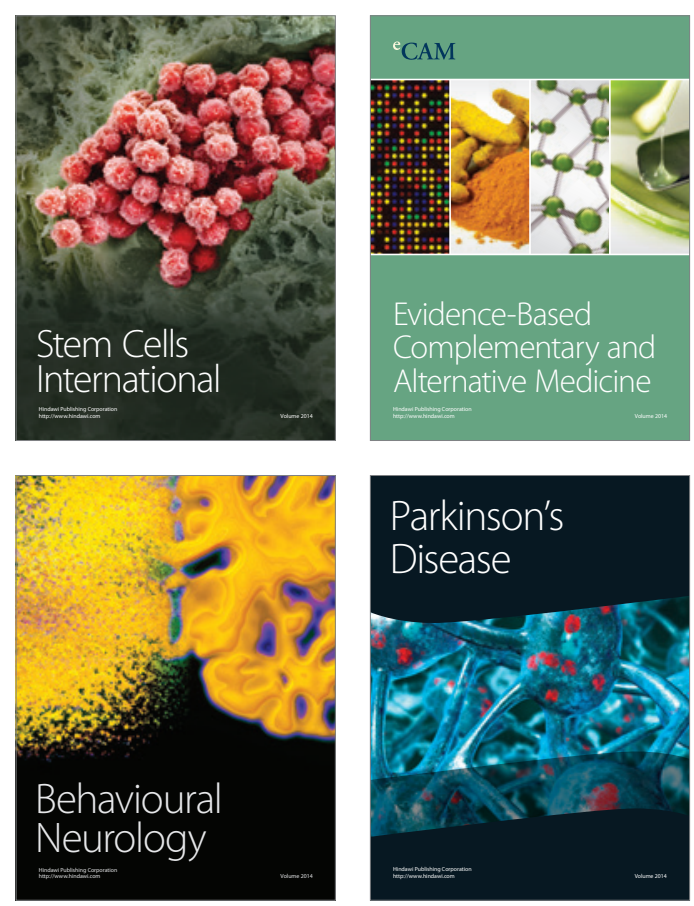

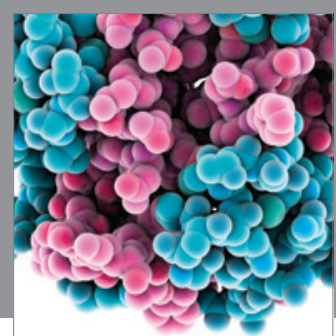

Journal of
Diabetes Research

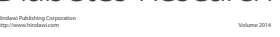

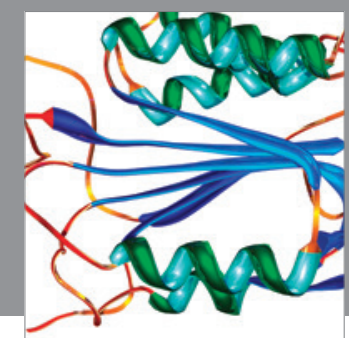

Disease Markers
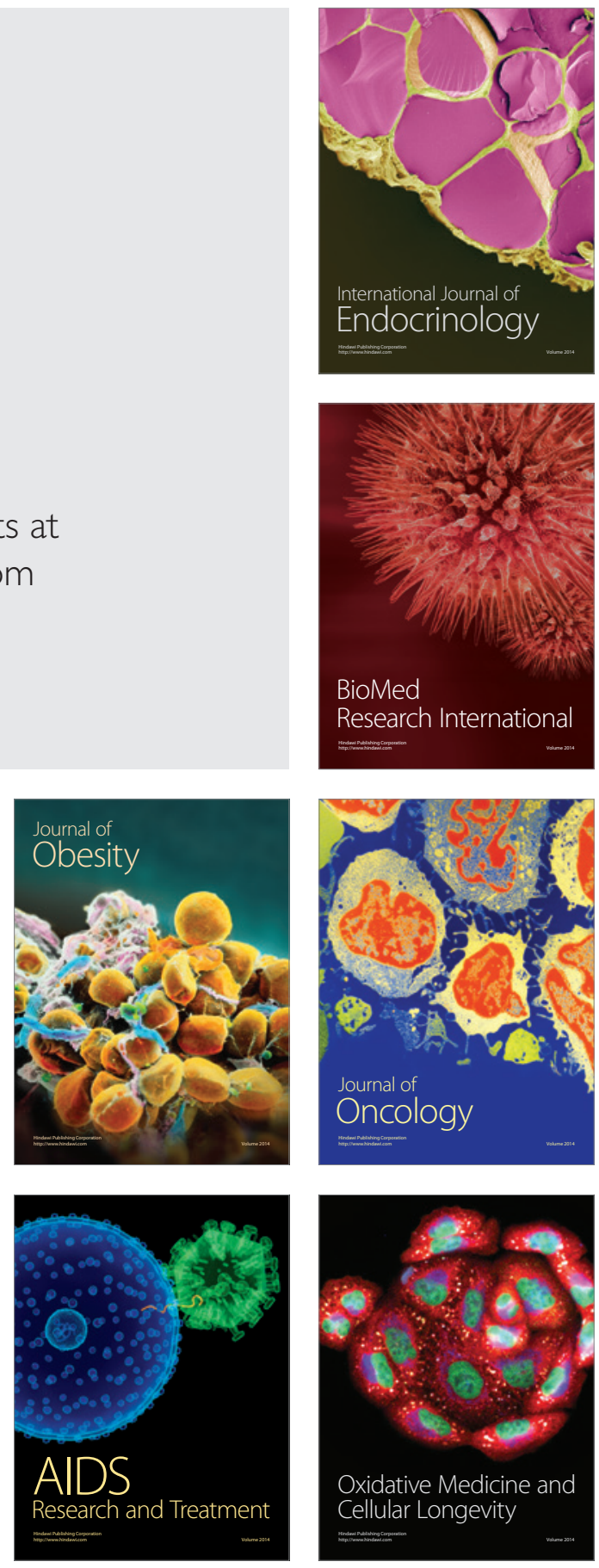